\title{
Kathrin Kaufhold*
}

\section{Transnational postgraduate students' experience of voice and participation}

\author{
https://doi.org/10.1515/applirev-2019-0143
}

\begin{abstract}
The article examines transnational students' experiences of participation in European higher education by applying the notion of voice that encompasses the capacity to communicate and to be heard (Hymes 1996. Ethnography, linguistics, narrative inequality: Toward an understanding of voice. London: Taylor \& Francis). Relating voice to access and participation, the article moves forward debates around incorporating students' multilingual knowledge resources in diverse writing practices in academia. It takes into account structural and ideological conditions as well as the creative potential of translanguaging in students' knowledge production. The instrumental case study explores the lived experiences of three multilingual students with highly diverse linguistic and educational backgrounds, who are enrolled in humanities master's programmes at a Swedish university. It investigates the students' perceptions of how they can make use of their linguistic and educational repertoires. The data derive from interviews around texts and audio-recorded writing diaries. The results demonstrate how translanguaging is mainly connected to writing for personal use and limited or regulated in assignment writing. They reveal multiple and contrasting ideological views on language use and knowledge, and highlight possibilities and obstacles for appropriating and recontextualising knowledge across languages, educational contexts and disciplines. The article thus connects translanguaging to questions of participation and access more broadly.
\end{abstract}

Keywords: voice, access, linguistic repertoire, transnational students, translanguaging

\section{Introduction}

European universities experience an increasing diversification partly due to internationalisation and migration processes especially at the postgraduate level.

*Corresponding author: Kathrin Kaufhold, Department of English, Stockholm University, Stockholm, 106 91, Sweden, E-mail: kathrin.kaufhold@english.su.se.

https://orcid.org/0000-0003-1925-0686

¿ Open Access. ๑ 2020 Kathrin Kaufhold, published by De Gruyter. (co)BY under the Creative Commons Attribution 4.0 International License. 
Some students belong to a "new global elite" (Vandrick 2011) of highly mobile, well-resourced students with experiences of living and studying in a range of countries, while others have less privileged but nevertheless mobile trajectories. Both groups can be characterised as transnational, meaning that they have mutual ties to family and other relations in a range of countries often using several languages (see Block 2017). Importantly, these students' educational biographies often reach across national borders and languages (Warriner 2007). In short, students bring a plethora of linguistic and educational experiences to postgraduate education.

Incorporating prior knowledge and students' experiences is central to learning. Writing scholars have described it as a starting point for further development (e. g. Belcher 2009) or explored ways of including this knowledge as legitimate resource for meaning making in academia (Lillis and Scott 2007). Recently, scholars have focused on involving languages and language varieties that students use besides the standard languages privileged in academia (Mazak and Carroll 2017). In pedagogic interventions students are encouraged to translanguage, i. e. to use several languages or language varieties in contact for meaning making (Canagarajah and Matsumoto 2017). At its best, the concept of translanguaging is, in Li Wei's words (2018: 15), "not conceived as an object or a linguistic structural phenomenon to describe and analyse but a practice and a process ... a process of knowledge construction that goes beyond language(s)". This concept of translanguaging goes beyond a focus on systems and speakers and describes a "linguistics of participation" (Rampton quoted in Li Wei 2018: 15).

At the same time, a language constitutes a symbolic resource (Heller 1995) and is connected to ideological views. Hence, translanguaging as participation requires criticality (cf. Li Wei 2011). Jones (2019) likens translanguaging to a space of negotiation where "the real world constraints of linguistic, racial, gender and economic domination are not swept under the rug" and compares it to "a marketplace, with all of its colours and contradictions, possibilities and dangers" (13). He thus points to the symbolic value of specific uses of language(s) in processes of knowledge construction.

To investigate such participation and to develop the notion of translanguaging as linguistics of participation in the institutional context of higher education, this article adds the sociolinguistic notion of voice as an analytical lens. Voice in this understanding comprises having access to and the means to construct knowledge, and having one's voice heard and accepted as legitimate contribution in academia (cf. Blommaert 2005). This understanding of voice has rarely been adopted in research on academic writing (see e. g. Thesen 2014 for an exception). Instead recent research (e. g. Canagarajah and Matsumoto 2017) has employed the term voice to describe negotiations of meaning in writing processes and reader 
responses, and applied this understanding within the safe space of the writing classroom in order to facilitate the "emergence of new voices" (p. 394). While such spaces are undoubtedly needed, there is a risk of overlooking the symbolic value associated with specific uses of language and dominant ways of knowledge construction.

The aim of this article is therefore to explore how transnational students experience possibilities or obstacles for participation (as voice in the sociolinguistic sense), and the role of their linguistic and educational resources in their regular master's programmes rather than in dedicated writing classes. It thus takes into account the students' experiences of power relations in higher education that can obstruct access to participation in the academic community (Wingate 2015). Since writing and written texts play a central role in displaying, testing and constructing knowledge in higher education, the study focuses on academic writing practices. Specifically, the article examines the experiences of three highly diverse transnational humanities postgraduate students through interviews and audiodiary recordings. The research questions are:

-What are the students' perceptions of ways in which they can draw on their linguistic and educational resources to participate in their master's programmes?

-What ideologies are salient in these accounts?

The experiences and ideologies expressed by the students illuminate patterns of participation in current northern European higher education. The article continues to rethink translanguaging in terms of participation as part of internationalisation and diversification processes in higher education.

\section{Translanguaging, repertoire and voice around academic writing}

In higher education, there is a growing interest in pedagogies that encourage students to use more than one language in and around academic writing (e. g. Antia and Dyers 2019; Canagarajah 2011; Li and Exley 2019 in Australia; Makalela 2017 in South Africa; Mazak et al. 2017 in the US/Puerto Rico), at times in transnational student projects (Porto and Byram 2015; You 2018). Such initiatives often take a translanguaging perspective, which encourages the use of multiple language codes, registers or other semiotic means for meaning making (Li Wei 2018). They move away from a view on languages as separate systems towards a focus on individual speaker's repertoires. In this view, considering language 
codes as separate entities is conditioned by the social context and dominant monolingual language ideologies (Heller 2007; Makoni and Pennycook 2006; Otheguyet al. 2015). Accordingly, language use is always ideological (Canagarajah and Matsumoto 2017). Such an understanding chimes well with Busch's (2017) conceptualisation of the linguistic repertoire which shapes language use. In this view, a speaker's linguistic repertoire comprises the interrelated dimensions of linguistic resources (i. e. linguistic knowledge), language ideologies (i. e. beliefs about language use) and affective experiences of this language use. It is acquired throughout a lifetime and specific aspects are made relevant in a given context.

These ideological and experiential dimensions of a speaker's linguistic repertoire are relevant in an environment where monolingual ideals of standard varieties are privileged by lecturers and students (e. g. Kuteeva 2020; Palfreyman and Al-Bataineh 2018). Zavala (2018: 175) cautions: "translanguaging pedagogy is not empowering per se. The relationship between linguistic practices and power depends on the language ideologies that exist in particular cultural contexts”, both inside and outside a writing classroom (see Matsuda 2014). Similarly, Jones (2019) suggests the creativity of translanguaging (i. e. combining semiotic resources in potentially new ways) also faces constraints of "the concrete, situated effectiveness of one's utterance” (pp. 6-7). Discussing Li Wei's (2011) point that translanguaging entails both creativity and criticality, Jones (2019: 7) suggests this criticality involves "recognizing how ideologies and power relations are constructed and reconstructed by the way we use language, as well as by the ways we are silenced". Busch's (2017) insights add that the (re)construction of language ideologies depends on the speaker's and others' beliefs about the language use as well as the speaker's affective experience. Thus, while a speaker might not objectively be silenced, language beliefs and experiences might reduce perceived possibilities to participate.

While the role of institutional power relations is important for fostering possibilities for participation (Gentil 2005; Stroud and Kerfoot 2013), it is equally important to recognise the students' active participation in reproducing and resisting such ideologies (Thesen 2014). To examine the diverse students' experiences of participation, the study adopts the sociolinguistic concept of voice, which has been influential in the work of some academic literacies scholars (e. g. Thesen 2014).

The term voice has been used variously in the different traditions of academic writing research, most prominently in the sense of authorial voice signalled by lexical items in texts (e. g. Hyland's (2008) analysis of metadiscourse). Increasingly scholars agree that voice is a social phenomenon which goes beyond author presence and intertextuality in written texts and takes into account reader 
responses (e. g. Jwa 2018; Tardy 2012), production processes (e. g. Dressen-Hammouda 2014; Ivanič and Camps 2001), or both (Canagarajah and Matsumoto 2017). This line of research often draws on Bakhtin's (1981) notion of voice as dialogic. Prior (2001) underlines that this dialogue is not simply an assimilation and adaptation of new discourse by an individual but an ongoing process of negotiating historically situated discourses in new situations.

Researchers with an interest in multilingual students' participation in knowledge production (especially in the South African context, e. g. Paxton 2012; Thesen 2014) acknowledge this socio-culturally situated and dialogic notion of voice and draw in addition on the sociolinguistic notion of voice envisaged by Hymes (1996) and developed by Blommaert (2005). In this view, voice combines "production and uptake" (Blommaert 2013: 443), for instance in writing and reading in specific situations. In addition, it considers the access to means of communication that can be valued across physical and social spaces, and ways of (re-)contextualising these resources as valuable within these spaces (Blommaert 2005: 76-78).

This article adopts this perspective to focus on how the students experience their language use and participation in knowledge production, how they position themselves in their accounts, and what ideologies they construct as salient. The research thus moves the debate on from translanguaging spaces, where multilingual language users enact linguistic repertoires creatively within the constraints of the specific social settings (Li Wei 2011), to participation spaces, a notion that problematises access and takes into account recontextualisation processes (cf. Kerfoot 2011).

\section{Methods}

The study is an instrumental case study (Stake 1995) to explore participation in the context of a diversifying student body at a Swedish university. To investigate students' experiences of participation through their language use around academic writing practices, the study comprises in-depth interviews (Kvale and Brinkman 2009) based on the students' texts (Lillis 2001), audio-diary (AD) recordings (Monrouxe 2009), and informal email exchanges. The students selected for this study are unique in their trajectories and their accounts are not generalisable. The aim is rather to develop an understanding of (Stake 1995) possibilities for participation in higher education from the students' perspectives. 


\subsection{Participants and data collection}

In line with the aim of an instrumental case study to explore a phenomenon, the article discusses the accounts of three master's students who were selected due to their highly distinct transnational backgrounds. The study is part of a wider research project on linguistic repertoires (see Kaufhold and Wennerberg 2020). The master's students were recruited through an announcement after an overview lecture on academic writing asking interested students to contact the researcher via email. Relevant for the recruitment was an experience of formal education outside of Sweden and the regular use of languages other than English and Swedish. In the university statistics (Statistics Sweden 2018), the selected students would fall into the separate categories of "international" (residing in Sweden for study purposes), so called "foreign background" (meaning born abroad of nonSwedish nationals) or "Nordic" (referring to the close collaboration between the Nordic countries). Instead of such a priori classifications and in line with Stroud and Kerfoot's (2013: 397) call for a "transformative epistemology", this study focuses on the diversity of their educational trajectories and reported language use. Table 1 provides an overview of the students, their reported languages and previous studies in various educational settings. The students currently study within humanities disciplines that are different from their undergraduate programmes. The selection of students also takes into account the use of two academic

Table 1: Overview of selected participants.

\begin{tabular}{|c|c|c|c|c|}
\hline Pseudonym & $\begin{array}{l}\text { Main } \\
\text { programme } \\
\text { language }\end{array}$ & $\begin{array}{l}\text { Reported } \\
\text { first } \\
\text { language }\end{array}$ & $\begin{array}{l}\text { Reported other } \\
\text { languages used } \\
\text { in HE }\end{array}$ & Previous studies \\
\hline Emma & English & Chinese & English, Swedish & $\begin{array}{l}\text { Comparative literature in } \\
\text { country of origin, } \\
\text { exchange year in } \\
\text { European country }\end{array}$ \\
\hline Vida & English & Arabic & English, Swedish & $\begin{array}{l}\text { Law and English Studies } \\
\text { in country of origin and } \\
\text { second country, Swedish } \\
\text { to achieve legitimation } \\
\text { for access to higher } \\
\text { education in Sweden }\end{array}$ \\
\hline Nick & $\begin{array}{l}\text { Swedish but } \\
\text { thesis in } \\
\text { English }\end{array}$ & $\begin{array}{l}\text { Finnish, } \\
\text { Swedish }^{\mathrm{a}}\end{array}$ & English & $\begin{array}{l}\text { History in Sweden, } \\
\text { bilingual secondary } \\
\text { school in country of origin }\end{array}$ \\
\hline
\end{tabular}

${ }^{\mathrm{a}}$ With Finnish reported as stronger language. 
Table 2: Overview of data from each student.

\begin{tabular}{|c|c|c|}
\hline Pseudonym & $\begin{array}{l}\text { Interview, } \\
\text { AD, email }\end{array}$ & Texts discussed in interview, (main) language of text \\
\hline Emma & $\begin{array}{l}\text { Interview 1, } 4 \text { ADs, } \\
\text { concluding email } \\
\text { exchange }\end{array}$ & $\begin{array}{l}\text { Text 1: undergraduate essay }{ }^{\mathrm{a}} \text {, Chinese } \\
\text { Text 2: recent essay, English }\end{array}$ \\
\hline Vida & Interview 1 & $\begin{array}{l}\text { Text 1-3: tasks }{ }^{\mathrm{b}} \text { from Swedish course, Swedish } \\
\text { Texts 4, 5: tasks from free-standing university } \\
\text { courses, English } \\
\text { Texts 6, 7: recent essay, English }\end{array}$ \\
\hline Nick & $\begin{array}{l}\text { Interview 1, } 4 \text { ADs, } \\
\text { concluding email } \\
\text { exchange }\end{array}$ & $\begin{array}{l}\text { Texts 1, 2: undergraduate course tasks, Swedish } \\
\text { Text 3: undergraduate thesis, Swedish } \\
\text { Text 4: postgraduate course task, Swedish }\end{array}$ \\
\hline
\end{tabular}

a essay describes a substantial analytic paper which is the main assignment of a course written at the end or after completion of a course.

${ }^{b}$ task describes a short discussion of a specific issue used as mid-term assignment or final assignment with a number of specific questions.

languages at Swedish universities with students using both or either Swedish or English.

The data comprise an initial interview discussing the students' experiences of their language use, a minimum of two self-selected texts written by the students for discussion in the interview, the recording of four $\mathrm{AD}$ recordings and a concluding email exchange to clarify issues deriving from the interview or ADs (see Table 2). For Vida, only the interview was completed due to time pressures. Nevertheless, her interview provides a rich discussion of her texts and was therefore included.

The interviews lasted between 46 and $77 \mathrm{~min}$. In line with research question one on perceptions of drawing on linguistic and educational resources and informed by Busch's notion of the linguistic repertoire (see Section 2), the interviews covered three topic areas: the students' perceived current and past use of different languages especially around academic literacy practices, views on their self-selected texts from different stages of their education, and experiences of their language use (see Appendix A). The main function of these texts was to anchor the accounts of experiences and any expressed language ideologies in concrete instances of language use (cf. Edley and Litosseliti 2010). The interviews were audiorecorded and transcribed verbatim. The transcription conventions used in this article can be found in Appendix B.

To extend the reflections from the interviews, students were asked to audiorecord observations on the use of their linguistic repertoire in their university studies over a period of four to eight weeks (see Appendix $C$ for instructions). The 
ADs, each lasting ca. $3 \mathrm{~min}$, provided further perspectives recorded in close proximity to self-selected "literacy events" (Barton 2007: 35) at a time and place convenient to the student (cf. Monrouxe 2009). Students were asked to submit the texts they discussed in the ADs. Before the interview, participants received information about the research and provided informed consent. They also received the transcripts of the interview and ADs with the possibility to withdraw or add information.

\subsection{Methods of data analysis}

The analysis of the interviews, ADs and emails commenced in two stages. Stage one entailed thematic coding guided by the theoretical framework and research questions, and refined by themes emerging from the transcripts. The codes include "linguistic resources" (Busch 2017), “educational resources” comprising knowledge of and "access to” (Blommaert 2005) discipline-specific concepts and writing processes, and “evaluations” related to experiences of language use (Busch 2017), i. e. explicit expressions of epistemic or affective attitudes (Conrad and Biber 2000). In addition, instances of reported "translanguaging" and "transitions" including comparisons between earlier and current experiences were identified. The codes served as retrieval mechanism and the cross-sectional indexing facilitated comparison across the highly diverse accounts (Mason 2002).

The interviews were partly informed by reading the students' texts closely to identify text samples as basis for discussing experiences of using various linguistic and educational resources. I paid special attention to lexical features different from the main language of the text and features of metadiscourse (following Hyland 2005), especially attitude markers (e. g. "surprisingly") and self-mentions ("I", "we").

Stage two examined the evaluations in the students' accounts specifically those related to language ideologies, i. e. expressions of beliefs around language use. These can comprise own evaluations or reported evaluations of one's language use by others. Following Du Bois' (2007) model of stance taking, evaluations are a means of social positioning of the speaker (dis-)aligning with a social group or institution. For instance, in Nick's claim "English as a language has been more relevant to me than Swedish", he evaluates English as relevant, positions himself as a user of English and aligns with those in his discipline who use English. Tracing how such evaluations are confirmed or contradicted throughout the data by one student and across students provides a useful tool to identify competing ideologies and experiences. 


\section{Results}

This section presents how the students perceived ways of using their linguistic and educational resources to participate in their study programmes, and the language ideologies salient in these accounts. The results are discussed in terms of participation and access along the three interrelated dimensions of voice: 1) voice as capacity to express and produce knowledge; 2) voice as access to knowledge production; and 3) voice as being heard. Most excerpts derive from the interviews. The excerpts from emails, ADs and the students' assignments are labelled as such.

\subsection{Voice as capacity for knowledge production}

Voice as capacity to express and produce knowledge includes the ability to use language to achieve one's goals (Blommaert 2013). The students repeatedly evaluated their ability to use several languages in their past and current studies. They thereby indicated perceived possibilities and obstacles for participating in knowledge production within the context of institutional language preferences.

Emma has some knowledge of Swedish which she uses in volunteering outside her university studies. She evaluates her English as more fluent in written than spoken interaction: (1) "when I read or when I write stuff, I can have the time to pause a bit and organise my language but not in the group discussion". Vida had worked hard to learn Swedish to meet the university entry requirements. Yet, she had to abandon her attempt to complete a freestanding module in Swedish because she felt her language skills were not advanced enough. Switching to the English version of the module, she commented: (2) "it's English, like you at least have an idea about what they are talking about but in Swedish it was totally impossible to get any notion about it". She evaluated her English use also in affective terms: (3) "the language that I really love is English it's like that I would like to achieve the academic level in English one day in my life".

Nick has in fact completed his secondary education at a Swedish-medium school but has negative recollections: (4) "the last thing in high school that my Swedish teacher said to me was, you will never survive in the world with your Swedish". He evaluates his early writing at university in comparison to his classmates (5) "they [his fellow students] used more complicated language than I did". While he has been reading English publications for his studies, he has relatively little experience of writing in academic English at master's level: "it is yet a bit foreign to me" (email). Nevertheless, he takes a strong positive stance towards English: 
(6) No matter how formal the language is, there is always a piece of my soul in my current academical writing. [... I I know I can do that in English, that through that language I can truly express myself and my passion [for the subject]. (email)

In these excerpts, the students express some confidence as well as doubts about their abilities to use standard varieties of Swedish and English. As evident throughout Section 4, these perceptions are informed by experiences of their ability to understand written and spoken discourse in academia, comparisons to others' language use, explicit feedback they received, and/or by their affective responses towards a language.

Mention of translanguaging instances was rare in the students' accounts and in their selected texts. A mix of language codes is only evident in Emma's references in Text 1 and Nick's use of specific Finnish and German terms in Texts 3 and 4. In both cases, Nick incorporates these terms in his texts and then discusses them using equivalent words in Swedish. He explains: (7) "because in the source material someone had used the term der oberste Gott [German: 'the highest God'] and then I wrote that it can also mean [provides explanation]”. This way of incorporating specific terms in their original language into an academic text written in another language has a long tradition.

For the most part, translanguaging is restricted to writing that is not meant to be shared or submitted (see Kaufhold and Wennerberg 2020). Instead, the students stress the use of the official course languages. Vida and Emma are particularly reserved about using their first languages.

(8) For the notes I use English but sometimes I would like maybe write one or two words in Arabic if it would help to explain something precisely. [...] Sometimes when it is extremely difficult for me to understand I would read in Arabic resources. Like I would write it in Arabic in Wikipedia or in whatever- Google. (Vida)

(9) There is a course last semester, [...] and the lecturer is talking about some philosophy ideas [...] when he talked about the ideas, I just got very struggled, like, to understand, so I googled the Chinese version in Wikipedia and I made notes in Chinese. That's the only time. I noted it down, like, in my own language to help me understand more about what he is talking about. (Emma)

The use of these languages is portrayed as an additional tool used in exceptional situations ("extremely difficult", "the only time”). Nevertheless, it is a useful strategy for meaning making.

Nick, whose course language is Swedish, presents a different perspective. He suggests that he draws on an additional language, English, for meaning making: (10) "If it's something that I can feel that I can easier summarise, then I write it in English. And the same goes for Finnish". Yet, he immediately qualifies this translingual approach by adding: (11) "When I read something, I tend to write it in 
Swedish because then it will be easier for me to remember that for the exam or assignment or whatever”. In this quote, Nick provides a vital reason for aligning with the institutionally favoured monolingual regime. What counts in the assignment will be the use of terms and display of knowledge in the appropriate register of the course language. The excerpts demonstrate that the students understand the potential of translanguaging for meaning making to some extent, e. $g$. for note taking, but orient at the same time to the institutional framing of monolingualism in relation to assignment writing.

\subsection{Voice as access to knowledge production}

Voice as access to knowledge production relates to the students' knowledge of subject-specific content and what Morrow (2009) calls “epistemological access", which encompasses "learning how to be a successful participant in an academic practice" (p. 78).

The students point to epistemological access when they report how they were able to draw on previous experiences of studying. For instance, Emma draws on her experience of writing essays in a different discipline and language: (12) "I still have a very clear idea of how to write things academically because I did lots of ((laugh)) essays, assignments in Chinese”. However, there are also moments when this knowledge cannot be mobilised across contexts. Vida, for instance, describes her first master's courses as (13): “I’ve just like- trying to survive like just read read and trying to um trying to do this homework". Despite having completed a degree in a different country, she feels "new to the system" in Sweden.

A major obstacle to participation discussed by the three students is their access to and use of conceptual knowledge across languages and disciplines. For Emma, it relates to having engaged with ideas of western philosophy in Chinese translations while now encountering philosophical ideas in English translations and in a different discipline.

(14) When I did my bachelor, it's all in Chinese and all the things are translated into Chinese, so I don't have to, like, go back to its English names, so I don't know them. So, that's a very big challenge for me actually. [...] I mean, when my classmates and I talk about, for example, we talk about western philosophy and I would say I know them [concepts], but not exactly. And I cannot talk to them about the ideas and the concepts I know because I don't know their English version.

In the excerpt, Emma evaluates her conceptual knowledge as partial in her current field of studies while her classmates have access to these concepts through a shared English version. Emma positions herself as being at a disadvantage in terms 
of producing knowledge in the communicative situation while nevertheless having some access to the knowledge.

This partial access to conceptual knowledge has consequences for her reading and writing. Emma repeatedly refers to the difficulties of appropriating knowledge and entextualising it. Referring to course tasks which involved reading academic texts and providing a response on an online forum, she explains: (15) "I feel like I'm not fully able to present what I think about this topic because I have to translate their ideas into my own and then present my own ideas on paper" (AD1). A sample of such a task discussed in AD3 exemplifies her appropriation. It contains a high proportion of direct quotes, for instance, in the second paragraph about 30 percent of the words are quotes. Its "assemblage” (cf. Canagarajah 2018: 33) style relies strongly on the original text but goes beyond mere ventriloquism as it creatively combines the ideas quoted, as illustrated below:

(16) In the societies of control, the pairs of individuals have dispersed and become "'dividuals,' and masses, samples, data, markets, or 'banks."”' This fragmentation accelerates the flows of information, posing what Deleuze called "the passive danger of entropy and the active danger of sabotage." (footnotes in the original omitted here)

In contrast, the final paragraph of the sample text contains Emma's analysis and multiple self-mentions with explicit expressions of author attitude (Hyland 2005) as can be illustrated by the first sentence that introduces her analysis: (17) "But several points remain unclear to me”. Comparing the two parts, Emma reflects:

(18) I find it much more easy to express my own opinions towards [own analysis] [...]. But still it can be very difficult for me to like have a very fluent- or fluent writing that I don't need to go back again check my grammar mistakes or sentence structure. And um yeah because I spend a lot of time just wondering, is it ok to write my reflections in this way or should I change it in another way, that my original thoughts somehow have been like interrupted [...] so the whole process appears to be very long and even a bit like torture. (AD3)

While it is easier to express her own analysis, her focus on formal language correctness slows her knowledge production down. Emma's doubts around accessing the advanced material, appropriating it and presenting it "correctly" reduce her potential for participation.

Besides these obstacles, the students emphasised the specific contributions to knowledge they can make because of their prior knowledge. When discussing Emma's Text 2, which dealt with an Asian phenomenon, she explained that she used English-medium sources but suspects that the authors are "Chinese-American" and suggested:

(19) Maybe I should write about these things because [... I feel like there is a responsibility to share my knowledge in Chinese and translate them to English, so that more people can know. 
In this case, Emma introduces the potential to contribute new perspectives. While initially positioning knowledge in English as most valuable, Emma introduces an alternative epistemological access. At this point, her knowledge of the language and the content become potentially a valuable resource.

The limitations to such linguistic and “local” knowledge are apparent in Vida's narrative of completing an assignment that included analysing an Arabic text and writing about it in English. Initially, she considered the task to be easy thinking that she had an advantage compared to her classmates who were learners of Arabic: (20) "the ability to study in my mother tongue, it's fantastic [...] all the students were like very struggling like exactly me when I study in English". However, she did not receive full marks because she had missed to translate and transliterate the Arabic quotes from the text. Vida learned later that this task requirement was in place to make the text accessible for readers without knowledge of Arabic, despite the fact that the source text had been read in class. In her account, Vida positions herself as resourceful when it comes to the understanding of the text, but as unaware of the task requirements necessary to contextualise her knowledge (cf. Blommaert 2005): (21) “that was completely new for me”.

Nick framed his access to conceptual knowledge as gradual development. In the past, he had (22) "avoided these theories because the language would be so complex". When comparing an earlier text [T2] with a recent text [T4], he explained how he had appropriated the concepts:

(23) I feel that this [T4] uses like a better language and more complex one, [...] the language [in T2] is much simpler and doesn't use difficult concepts. And this one [T4] has no problem using them, using them correctly.

In his account, he provides a developmental journey and positions himself as diligent, successful and increasingly confident student. His move between disciplines hardly affects his ability to mobilise his knowledge across contexts. Vida and Emma, who changed not only disciplines but also educational systems across countries and languages, feel that they can mobilise only some of their linguistic and educational resources, which partly obstructs their participation.

\subsection{Voice as being heard}

Voice goes beyond the ability to communicate and make meaning; it includes being heard and understood (Hymes 1996). This section discusses the perceived uptake of the students' writing by looking at the reported feedback on their texts. 
Vida discussed the feedback for two short pieces of course work that she submitted around the same time. She evaluated both courses as enjoyable and the topics "interesting to read about". Both texts deviate from standard English forms. Text seven received a high grade and Text 6 a low grade by different assessors. The most salient difference in the textual form is the variety of metadiscourse.

Text seven begins factually by introducing a central concept for the essay leading towards a definition. Throughout discursive markers are used to guide the reader often connected to self-mentions ("we") as illustrated in the opening lines:

(24) In order to outline the North American Regionalism, and to analyze it from the perspective of (Regions and Powers) R\&P, discussing this conception from other perspectives on North American and on regionalism, We need first to present a definition of the term 'Region' since that the regions are currently central to our understanding of world politics.

The top grade this assignment received indicates that the content was recognised as valuable by the assessor. Since no further feedback was given, it remains however unclear to Vida what made this text valuable to be heard.

Text six includes various forms of metadiscourse as illustrated by the opening sentences:

(25) Differences make the world a more interesting place, and accepting them could be the key to create the required balance in this world. [...] So we need to realize that 'the respect' should be the main thing between all cultures.

When I think about the Middle East and North-Africa in the past, I think about literature, stories and divinity... about Damascus; the eldest city in the world... I think about first civilizations, religion, richness and the Sun.

The assignment opens with a bold claim and some hedging ("could be"), followed by attitude markers expressing obligation ("need", "should") and markers of reader engagement through the inclusive "we". The epistemic attitude marker "I think" introduces her "experiential knowledge" (Cooper 2011: 41) most noticeably in the reference to the sun, spelt with a capital letter. The sun gains significance when considering that she wrote this text in a Swedish late autumn with relatively short periods of daylight (to which she refers in the interview: "[studying] depends on the mood and the weather").

Vida was disappointed about the low grade she received for this assignment:

(26) I'm actually sad about this that I got a [low mark] for this one. Like if you read it you might like probably- like I quoted from Wikipedia which is not good and academic enough but I think I deserve more.

In reflecting on the reasons for her low grade, she partly aligns with the assessment ("not academic enough"). She then read out the assessor's 
feedback, which appreciates (27) "the effort and the spirit" of the paper but critiques its form (28): "it is poorly realised, formatted entirely inappropriately", and advises to "learn how to write an academic paper". Vida backgrounds the focus on form and foregrounds her effort later in the interview: (29) "I worked on this so much". The assessor only partially recognises Vida's engagement and experiential knowledge and disqualifies her voice from being heard based on the textual form.

As discussed above, Emma is self-critical on the form of her text both in terms of standard English constructions and argument presentation. She returns to this when reflecting on feedback she received:

(30) They always say that there are lots of grammar mistakes, or, you need to improve youryou need to express clearly, so that there will be no misunderstanding of your ideas [...] the feedback is that I can find very original ideas [...] but like yeah, the ideas is not very clear. So, I'm trying to figure out myself, like, how to express things clearly. Cause sometimes when I read the essays and papers in our [programme], I would find their ideas is not very clear either.

Emma observes at the end of this excerpt that "clarity" is a complex concept. Indeed, clarity depends on discipline-specific ways of communication (Lea and Street 1998) rather than objective explicitness (Biber and Grey 2016). The reported feedback suggests that Emma only partially succeeds in mobilising her resources in a form that is fully accepted by her assessors.

Nick on the other hand seems to play with textual clarity while challenging grammatical correctness. He provides the example of using hyphens and incomplete clauses:

(31) Because when you get over a certain level and you get more confident, then you can just start spewing out content without really understanding that this is something that is getting too complicated. And that's something that I sometimes have to deal with when I write in Swedish or in English [...] this ((pointing at T3)) has been proofread [...] I know that there has been multiple sentences that had been cut in half, because you see that I love using these thought lines [hyphens], you know, [...] here, [reads in Swedish (translation by author): “This logo contains a lot of symbols - the swan ...”]. I could have written that, [in Swedish (translation by author): "This logo contains a lot of symbols, for example the swan ..."]. That would probably have been much more logical and grammatically more correct.

He evaluates his Swedish academic writing as somewhat deviating from an ideal of language correctness with complete sentences and less information "cram [med] in". This evaluation is supported by his proofreaders: "my parents [...] said, ok, this sentence is too long". At the same time, he evaluates this perceived violation of academic conventions as something he enjoys doing. Considering that Text 3 has been proofread, the remaining "long sentences" he identifies do 
not seem to impede his voice being heard. While Vida and Emma experience that they are limited by explicit and implicit formal conventions, Nick, with his socialisation into Swedish academic writing and additional access to proofreading support, suggests he can insert some minor violations to expected textual forms.

\section{Discussion and conclusion: Voice and participation}

The article explored how three transnational students experience possibilities for participation and the role of their diverse linguistic and educational repertoires. The students discussed in this article draw on highly diverse educational and linguistic resources and frame their experiences in different ways. Therefore, they cannot stand as representatives of specific student groups. Rather than providing a comparison, their accounts illustrate the struggles student writers experience when developing means of communication and gauging norms of uptake that govern participation and assessment practices (Thesen 2014). They reveal the multiple and contrasting (Jones 2019) ideological views on language use and knowledge.

With reference to research question one concerning the students' perceived use of linguistic and educational resources, the students emphasise the use of one of the official university languages, Swedish or English. As observed elsewhere (e. g. Van Viegen and Zappa-Hollman 2019), other languages are mainly valued for meaning making in personal notes and private spaces (8-10). Notable exceptions are Nick's use of specific terms in other languages that are central to his essay (7) and Vida's Arabic text assignment (20).

The three students frame possibilities to draw on their previous educational experience in different ways. Nick mentions his initial avoidance of complex concepts (22) and doubts about some formal presentation of his text (31) but highlights his gradual development of privileged ways of academic knowledge production (23). Similar to Ianelli and Huang's (2014) finding that Chinese students with prior experience of the UK education system seemed to be better prepared for studying at UK universities, Nick's undergraduate experience of Swedish higher education enabled a gradual familiarisation with ways of participating in local academic practices. Emma and Vida, in contrast, emphasise the novel aspects of accessing and participating in knowledge production (13, 14). Yet, across cases, we can see the importance of recontextualising and appropriating linguistic and educational resources (15, 21, 22) (cf. Minkyung and 
Belcher 2018). Emma explains this in terms of "translating ideas" across languages and ways of thinking (15), representing it as translanguaging in an "inner dialogue" (Prior 2001: 73).

Possibilities of using certain types of knowledge and ways of meaning making that deviate from abstract academic knowledge production and standard textual forms (Cooper 2011; Tuck 2016) are disqualified by assessors $(28,30)$ or by students' perceptions of institutional requirements $(11,18,26,31)$. Translanguaging in assignment texts is limited by the students' and assessors' alignment with institutional conventions, as displayed most clearly in Vida's Arabic text example (21). Nevertheless, the students' accounts indicate that assessors partially recognise efforts and ideas in assignments. Further research could explore lecturers' (at times contradictory) experiences of assessing "unconventional" ways of knowledge production, orientations to monolingual standards (cf. Kuteeva 2020), institutional gatekeeping (cf. Thesen 2014), and national guidelines for equal access to knowledge production (e. g. Swedish Council for Higher Education 2016).

In terms of the ideologies that are salient in the students' accounts, the results are in line with findings of language hierarchies where English is highly valued (Risager 2012) and oriented to as international language. In addition to its utilitarian value, Vida and Nick evaluate English in positive affective terms $(3,6)$. Swedish can take the prime position if it is the dominant course language (11). Languages are perceived and valued differently for different purposes in different social spaces (for public assignments or private notes) (cf. Kaufhold and Wennerberg 2020).

The accounts add that access to knowledge production is equally ideologically laden. For instance, Vida readily accepts that any Arabic quote requires a translation and transliteration (21) despite the fact that the setting, where students and assessors read the text in Arabic, would have facilitated meaning making across languages. Emma initially privileges Anglophone interpretations of western philosophy encoded in specific terms that are the basis for engagement on her course. Renderings of these theories in Chinese and in the context of her previous studies are less valuable and reduce her participation (14). This might at first glance be interpreted as "practices of epistemological hegemony" (Manathunga 2015: 15) where only western writings in English are accepted as valid sources. Yet, the fact that Emma counters this perspective with potentially being an ambassador of eastern knowledge (19) implies the competing ideologies she negotiates. Thus, higher education is not only a marketplace where language has symbolic value (cf. Jones 2019) but where epistemological access more broadly is negotiated (see Stroud and Kerfoot 2020 for a more radical discussion). 
The perspective of voice applied in this article moves us beyond creativity and criticality that are central to translanguaging as a linguistics of participation (Li Wei 2018). It sheds light on the role of access to means of knowledge production "which circulate in unequal ways in social networks and discursive spaces" (Heller 2007: 2). Voice as capacity to produce knowledge and being heard is saturated with ideological beliefs about language and knowledge (cf. Xu and Grant 2017). These beliefs are reproduced and at times challenged $(29,30,31)$ by students with diverse linguistic and educational repertoires irrespective of statistical categories, such as "international" or "foreign background". Interventions in higher education pedagogy that encourage translanguaging for meaning making need to consider voice in its three dimensions to achieve what Hymes (1996: 64) envisaged: "freedom to have one's voice heard" and "freedom to develop a voice worth hearing".

Research Funding: This research did not receive any specific grant from funding agencies in the public, commercial, or not-for-profit sectors.

\section{Appendix A: Interview schedule}

The interview schedule included the following topics. It was individually tailored for the specific student drawing on any information that the students provided in their first contact email (e. g. one student suggesting that they experienced issues around multilingualism in specific contexts of secondary or tertiary education), and based on the text samples they sent before the interview.

1. Language use at university (current and past):

- Thinking about your current learning and specific situations today or this week, could you please talk about your language use in the different situations listed below:

Languages I hear in lectures, I hear/use in seminars, I use in group work, I read, I write assignments in, I use for making notes, and Languages I use on other occasions for my education (please specify the occasion), e. g. discussing course work with family or friends.

- Please tell me about your previous studies: What did you study before your masters? Could you describe your language use on that programme (based on the list above)?

- Follow up on comparisons.

2. Self-selected texts (past and recent):

- Could you please tell me about the texts you chose: What are they? Why did you choose them? 
- Do you remember how you went about writing these texts? (e. g. formulate a research aim, collect material, etc.)

- What was similar in the process of writing these texts? What was different?

- How did it feel to write in the different languages?

- How did others who read the texts react?

- Specific questions based on texts: e. g. choice of terms in different languages, sources in different languages, self-mentions in text.

3. Language experience:

- Can you think of an image or a metaphor that describes yourself as a user of many languages?

- What do you think is most important when learning to write academically in one's own and/or another language?

Is there anything else you'd like to add?

\title{
Appendix B Transcription conventions
}

\author{
Transcription symbols \\ te- Break off \\ ((text)) Non-verbal information such as laughter \\ [...] Omitted text \\ [text] Additional information added for clarity by the author
}

\section{Notes}

In the interview excerpts, capitals and punctuation have been added to facilitate reading.

In the excerpts from the students' texts, no changes were made to the original text. Text omitted from the original text is indicated by [...].

\section{Appendix C: Instructions for the audio diary}

The instructions for the audio-diary recordings were given as part of the information on the research project as follows:

"The audio diary involves that you audio-record about five short (2-3 min) observations on your uses of languages during the process of some academic writing over the duration of ca. 4 weeks. I would like to collect these recordings together with samples of the texts these observations refer to." After the interview, 
a reminder of the instructions was provided using examples of language use discussed in the interview.

\section{References}

Antia, Bassey E. \& Charlyn Dyers. 2019. De-alienating the academy: Multilingual teaching as decolonial pedagogy. Linguistics and Education 51. 91-100.

Bakhtin, Mikhail M. 1981. The dialogic imagination: Four essays by M. Bakhtin. Translated by Michael Holquist. Austin: University of Texas Press.

Barton, David. 2007. Literacy: An introduction to the ecology of written language, 2nd edn. Oxford: Blackwell.

Belcher, Diane. 2009. What ESP is and can be: An introduction. In Diane Belcher (ed.), English for Specific Purposes in theory and practice, 1-19. Ann Arbor, M.I.: University of Michigan Press.

Biber, Douglas \& Bethany Gray. 2016. Grammatical complexity in academic English: Linguistic change in writing. Cambridge: Cambridge University Press.

Block, David. 2017. Social class in migration, identity, and language research. In Suresh Canagarajah (ed.), The Routledge handbook of migration and language, 133-148. New York: Routledge.

Blommaert, Jan. 2005. Discourse. Cambridge: Cambridge University Press.

Blommaert, Jan. 2013. Writing as a sociolinguistic object. Journal of Sociolinguistics 17(4). 440-459.

Busch, Brigitta. 2017. Expanding the notion of The linguistic repertoire: On the concept of spracherleben - The lived experience of language. Applied Linguistics 38(3). 340-358.

Canagarajah, Suresh. 2011. Codemeshing in academic writing: Identifying teachable strategies of translanguaging. The Modern Language Journal 95(3). 401-417.

Canagarajah, Suresh. 2018. Translingual practice as spatial repertoires: Expanding the paradigm beyond structuralist orientations. Applied Linguistics 39(1). 31-54.

Canagarajah, Suresh \& Yumi Matsumoto. 2017. Negotiating voice in translingual literacies: From literacy regimes to contact zones. Journal of Multilingual and Multicultural Development 38(5). 390-406.

Conrad, Susan \& Douglas Biber. 2000. Adverbial marking of stance in speech and writing. In Susan Hunston \& Geoffrey Thompson (eds.), Evaluation in text: Authorial stance and the construction of discourse, 56-73. Oxford University Press.

Cooper, Linda. 2011. Activists within the academy: The role of prior experience in adult learners' acquisition of postgraduate literacies in a postapartheid South African university. Adult Education Quarterly 61(1). 40-56.

Dressen-Hammouda, Dacia. 2014. Measuring the voice of disciplinarity in scientific writing: A longitudinal exploration of experienced writers in geology. English for Specific Purposes 34. 14-25.

Du Bois, John. 2007. The stance triangle. In Robert Englebretson (ed.), Stance taking in discourse, 139-182. Amsterdam: Benjamins.

Edley, Nigel \& Lia Litosseliti. 2010. Contemplating interviews and focus groups. In Lia Litosseliti (ed.), Research methods in linguistics, 155-179. London: Continuum.

Gentil, Guillaume. 2005. Commitments to academic biliteracy: Case studies of francophone university writers. Written Communication 22(4). 421-471. 
Heller, Monica. 1995. Language choice, social institutions, and symbolic domination. Language in Society 24. 373-405.

Heller, Monica. 2007. Bilingualism as ideology and practice. In Monica Heller (ed.), Bilingualism: $A$ social approach, 1-22. New York: Palgrave.

Hyland, Ken. 2005. Metadiscourse: Exploring interaction in writing. London: Bloomsbury.

Hyland, Ken. 2008. Disciplinary voices: Interaction in research writing. English Text Construction 1(1). 5-22.

Hymes, Dell. 1996. Ethnography, linguistics, narrative inequality: Toward an understanding of voice. London: Taylor \& Francis.

Ianelli, Christina \& Jun Huang. 2014. Trends and participation in attainment of Chinese students in UK higher education. Studies in Higher Education 39(5). 805-822.

Ivanič, Roz \& David Camps. 2001. I am how i sound: Voice as self-representation in L2 writing. Journal of Second Language Writing 10. 3-33.

Jones, Rodney. 2019. Creativity in language learning and teaching: Translingual practices and transcultural identities. Applied Linguistics Review. https://doi.org/10.1515/applirev-20180114 (in press).

Jwa, Soomin. 2018. Negotiating Voice construction between writers and readers in college writing: A case study of an L2 writer. Journal of Language, Identity \& Education 17(1). 34-47.

Kaufhold, Kathrin \& Jeanna Wennerberg. 2020. "I need to know this in Swedish because it's the kärnspråkl”: Language ideologies and practices of multilingual students. In Maria Kuteeva, Kathrin Kaufhold \& Niina Hynninen (eds.), Language perceptions and practices in multilingual universities, 193-216. Cham: Palgrave Macmillan.

Kerfoot, Caroline. 2011. Making and shaping participatory spaces: Resemiotization and citizenship agency in South Africa. International Multilingual Research Journal 5. 87-102.

Kuteeva, Maria. 2020. If not English then what? Unpacking language hierarchies at university. In Maria Kuteeva, Kathrin Kaufhold \& Niina Hynninen (eds.), Language perceptions and practices in multilingual universities, 27-56. Cham: Palgrave Macmillan.

Kvale, Steinar \& Svend Brinkman. 2009. InterViews: Learning the craft of qualitative research interviewing. London: Sage.

Lea, Mary \& Brian Street. (1998). Student writing in higher education: An academic literacies approach. Studies in Higher Education 23(2). 157-172.

Li Wei. 2011. Moment analysis and translanguaging space: Discursive construction of identities by multilingual Chinese youth in Britain. Journal of Pragmatics 43(5). 1222-1235.

Li Wei. 2018. Translanguaging as a practical theory of language. Applied Linguistics 39(1). 9-30.

Li, Minglin \& Beryl Exley. 2019. Benefits of translanguaging and transculturation exchanges between international higher degree research students and English medium research supervisors. In Indika Liyanage \& Tony Walker (eds.), Multilingual education yearbook 2019, 121-135. Berlin: Springer.

Lillis, Theresa. 2001. Student writing: Access, regulation, desire. London: Routledge.

Lillis, Theresa \& Mary Scott. 2007. Defining academic literacies research: Issues of epistemology, ideology and strategy. Journal of Applied Linguistics 4(1). 5-32.

Makalela, Leketi. 2017. Translanguaging practices in a South African institution of higher learning: A case of ubuntu multilingual return. In Catherine M. Mazak \& Kevin S. Carroll (eds.), Translanguaging in higher education: Beyond monolingual ideologies, 11-28. Bristol: Multilingual Matters. 
Makoni, Sinfree \& Alastair Pennycook. 2006. Disinventing and reconstituting languages. In Sinfree Makoni \& Alastair Pennycook (eds.), Disinventing and reconstituting language, 1-41. Clevedon: Multilingual Matters.

Manathunga, Catherine. 2015. Transcultural and postcolonial explorations: Unsettling education. The International Education Journal: Comparative Perspectives 14(2). 10-21.

Mason, Jennifer. 2002. Qualitative researching, 2nd edn. London: Sage.

Matsuda, Paul Kei. 2014. The lure of translingual writing. PMLA 129(3). 478-483.

Mazak, Catherine M. \& Kevin S. Carroll (eds.). 2017. Translanguaging in higher education: Beyond monolingual ideologies. Bristol: Multilingual Matters.

Mazak, Catherine M., A. J. Rivera \& Lauren Pérez Mangonéz. 2017. Translanguaging in university literacy practices: Bilingual collaboration around English texts. In David. M. Palfreyman \& Christa Van der Walt (eds.), Academic biliteracies: Multilingual repertoires in higher education, 58-75. Bristol: MultilingualMatters.

Minkyung, Kim \& Diane D. Belcher. 2018. Building genre knowledge in second language writers during study abroad in higher education. Journal of English for Academic Purposes 35. 56-69.

Monrouxe, Lynn V. 2009. Solicited audio diaries in longitudinal narrative research: A view from inside. Qualitative Research 9(1). 81-103.

Morrow, Wally. 2009. Bounds of democracy: Epistemological access in higher education. Cape Town: HSRC Press.

Otheguy, Ricardo, Ofelia García \& Wallis Reid. 2015. Clarifying translanguaging and deconstructing named languages: A perspective from linguistics. Applied Linguistics Review 6(3). 281-307.

Palfreyman, David M. \& Afaf Al-Bataineh. 2018. 'This is my life style, Arabic and English': Students' attitudes to (trans)languaging in a bilingual university context. Language Awareness 27(1-2). 79-95.

Paxton, Moragh. 2012. Student voice as a methodological issue in academic literacies research. Higher Education Research \& Development 31(3). 381-391.

Porto, Melina \& Michael Byram. 2015. A curriculum for action in the community and intercultural citizenship in higher education. Language, Culture and Curriculum 28(3). 226-242.

Prior, Paul. 2001. Voices in text, mind, and society: Sociohistoric accounts of discourse acquisition and use. Journal of Second Language Writing 10(1). 55-81.

Risager, Karen. 2012. Language hierarchies at the international university. International Journal of the Sociology of Language 216. 111-130.

Stake, Robert E. 1995. The art of case study research. Thousand Oaks, CA: Sage.

Statistics Sweden. 2018. Education and research. Statistics Sweden. https://www.scb.se/en/ finding-statistics/statistics-by-subject-area/education-and-research (accessed 23 September 2019).

Stroud, Chris \& Caroline Kerfoot. 2013. Towards rethinking multilingualism and language policy for academic literacies. Linguistics and Education 24(4). 396-405.

Stroud, Chris \& Caroline Kerfoot. 2020. Decolonising higher education: Multilingualism, linguistic citizenship \& epistemic justice. Working Papers in Urban Language \& Literacies Nr. 265. https://kcl.academia.edu/WorkingPapersinUrbanLanguageLiteracies (accessed 20 March 2020).

Swedish Council for Higher Education. 2016. Can excellence be achieved in homogeneous student groups? https://www.uhr.se/english (accessed 28 April 2020).

Tardy, Christine M. 2012. Voice construction, assessment, and extra-textual identity. Research in the Teaching of English 47(1). 64-99. 
Thesen, Lucia. 2014. Risk as productive: Working with dilemmas in writing of research. In Lucia Thesen \& Linda Cooper (eds.), Risk in academic writing: Postgraduate students, their teachers and the making of knowledge, 1-24. Bristol: Multilingual Matters.

Tuck, Jackie. 2016. 'That ain't going to get you a professorship' work with student writers in UK higher education. Studies in Higher Education 41(9). 1612-1626.

Van Viegen, Saskia \& Sandra Zappa-Hollman. 2019. Plurilingual pedagogies at the postsecondary level: Possibilities for intentional engagement with students' diverse linguistic repertoires. Language, Culture and Curriculum. 33(2). 172-187.

Vandrick, Stephanie. 2011. Students of the new global elite. TESOL Quarterly 45(1). 160-169.

Warriner, Doris S. 2007. Transnational literacies: Immigration, language learning, and identity. Linguistics and Education 18. 201-214.

Wingate, Ursula. 2015. Academic literacy and student diversity: The case for inclusive practice. Bristol: Multilingual Matters.

Xu, Linlin \& Barbara Grant. 2017. International doctoral students' becoming: A dialogic perspective. Innovations in Education and Teaching International 54(6). 570-579.

You, Xiaoye. 2018. Introduction: Making a transnational turn in writing education. In Xiaoye You (ed.), Transnational writing education: Theory, history, and practice, 1-17. New York: Routledge.

Zavala, Virginia. 2018. Translanguaging pedagogies and power: A view from the south. Language and Education 33(2). 174-177. 